\title{
Real-time PCR Quantification and Mycotoxin Production of Fusarium graminearum in Wheat Inoculated with Isolates Collected from Potato, Sugar Beet, and Wheat
}

\author{
Rishi R. Burlakoti, Rolando Estrada, Jr., Viviana V. Rivera, \\ Anuradha Boddeda, Gary A. Secor, and Tika B. Adhikari
}

First, second, third, fifth, and sixth authors: Department of Plant Pathology, 306 Walster Hall, and fourth author: Department of Veterinary and Microbiological Sciences, Van Es Hall, North Dakota State University, Fargo 58105.

Accepted for publication 2 February 2007.

\begin{abstract}
Burlakoti, R. R., Estrada, R., Jr., Rivera, V. V., Boddeda, A., Secor, G. A., and Adhikari, T. B. 2007. Real-time PCR quantification and mycotoxin production of Fusarium graminearum in wheat inoculated with isolates collected from potato, sugar beet, and wheat. Phytopathology 97:835841.

Fusarium graminearum causes Fusarium head blight (FHB) in small grains worldwide. Although primarily a pathogen of cereals, it also can infect noncereal crops such as potato and sugar beet in the United States. We used a real-time polymerase chain reaction (PCR) method based on intergenic sequences specific to the trichodiene synthase gene (Tri5) from $F$. graminearum. TaqMan probe and primers were designed and used to estimate DNA content of the pathogen (FgDNA) in the susceptible wheat $\mathrm{cv}$. Grandin after inoculation with the 21 isolates of $F$. graminearum collected from potato, sugar beet, and wheat. The presence of nine mycotoxins was analyzed in the inoculated wheat heads by gas chromatography and mass spectrometry. All isolates contained the Tri5 gene and were
\end{abstract}

ABSTRACT

Fusarium head blight (FHB), also known as scab, is a devastating disease of small grains worldwide (22). Until now, 17 causal organisms associated with scab have been reported (31). Among them, Fusarium graminearum Schwabe (teleomorph Gibberella zeae), is the most devastating pathogen of wheat and barley in the United States $(2,22)$. The disease can cause significant yield losses (31) and reduce grain quality due to production of mycotoxins (2,22). Some Fusarium spp. produce both type A and type B trichothecenes (32). Type B trichothecenes, such as nivalenol, (NIV), deoxynivalenol (DON), 3-acetyldeoxynivalenol (3ADON), 15-acetyldeoxynivalenol (15-ADON), and fusarenon $\mathrm{X}$ (FX) (32), have been the most extensively studied and characterized (7). These mycotoxins are hazardous to both human and animal health, and reduce the price and marketability of small grains significantly $(20,22,31)$.

Traditionally, quantification of Fusarium spp. occurring on wheat includes assessing disease severity or incidence (infected spikelets) (38) and counting fungal spores (20). These methods are tedious and time consuming when large samples have to be processed. Several immunological and molecular techniques have been developed to detect and quantify Fusarium spp., including $F$. graminearum $(11,28,29,33,41)$. The main advantage of realtime polymerase chain reaction (PCR) assay over end-point

Corresponding author: T. B. Adhikari; E-mail address: tika.adhikari@ndsu.edu

doi:10.1094/PHYTO-97-7-0835

(C) 2007 The American Phytopathological Society virulent to $\mathrm{cv}$. Grandin. Isolates of $F$. graminearum differed significantly in virulence (expressed as disease severity), FgDNA content, and mycotoxin accumulation. Potato isolates showed greater variability in producing different mycotoxins than sugar beet and wheat isolates. Correlation analysis showed a significant $(P<0.001)$ positive relationship between FgDNA content and FHB severity or deoxynivalenol (DON) production. Moreover, a significant $(P<0.001)$ positive correlation between FHB severity and DON content was observed. Our findings revealed that $F$. graminearum causing potato dry rot and sugar beet decay could be potential sources of inoculum for FHB epidemics in wheat. Real-time PCR assay provides sensitive and accurate quantification of $F$. graminearum in wheat and can be useful for monitoring the colonization of wheat grains by $F$. graminearum in controlled environments, and evaluating wheat germplasms for resistance to FHB.

Additional keywords: aggressiveness, detection, Gibberella zeae, nivalenol, trichothecenes. quantitative PCR is that the amplification products can be monitored as they are accumulated in the exponential phase (34), thus allowing precise measurement of FgDNA content in the reaction. SYBR Green real-time PCR has been developed using the sequence of the Tri5 gene for the specific detection of trichothecene-producing Fusarium spp. (35). Because SYBR Green binds nonspecifically to double-stranded DNA, detection assays that use this technology must be optimized carefully to avoid false positives. TaqMan probe binds to its target DNA sequence, thus allowing more accurate quantification $(34,41)$.

In recent years, the host range of $F$. graminearum has expanded from cereals to noncereal crops such as dry bean (C. Bradley, personnel communication), canola (5), potato (1), soybean $(4,21)$, and sugar beet (15). Although preliminary results showed that the isolates of $F$. graminearum from potato and sugar beet can infect wheat (12), the toxigenic potential of these isolates has not yet been assessed. Our hypothesis was to determine whether isolates of $F$. graminearum collected from other crops such as potato and sugar beet can cause FHB of wheat and produce mycotoxins. The specific objectives of this study were to (i) compare virulence (aggressiveness) of the isolates of $F$. graminearum collected from potato, sugar beet, and wheat in the susceptible wheat cv. Grandin, (ii) use a real-time PCR assay based on TaqMan probe and the Tri5 gene to detect and estimate the DNA content of these isolates of $F$. graminearum in the susceptible wheat cv. Grandin in the greenhouse, (iii) quantify mycotoxins produced by these isolates of $F$. graminearum in wheat heads, and (iv) determine the relationships between FgDNA content, FHB severity, and mycotoxin accumulation. 


\section{MATERIALS AND METHODS}

Identification of $\boldsymbol{F}$. graminearum. Over 300 isolates of F. graminearum were collected from infected potato tubers, sugar beet taproots, and wheat heads in Idaho, Minnesota, and North Dakota between 2004 and 2005. Infected potato tubers, sugar beet taproots, and wheat kernels were surface sterilized with 5\% sodium hypochlorite solution and cultured in Komada medium (17) for 8 to 10 days. To identify F. graminearum, morphological characteristics were examined on different culture media (26). These characteristics included the carmine coloration of the underside of the culture, presence of white fluffy mycelium, and production of large distinct macro conidia while growing in halfstrength potato dextrose agar (PDA) medium (100 g of potato, $10 \mathrm{~g}$ of dextrose, and $10 \mathrm{~g}$ of agar). In addition, the isolates were grown on carnation leaf agar (CLA) medium to confirm the production of perithecia. Single-spore cultures were prepared for each isolate on PDA. A subset of 21 isolates of F. graminearum (6 isolates from potato, 5 from sugar beet, and 10 from wheat) were selected randomly and used in this study (Table 1). All isolates were preserved as mycelial plugs in $30 \%$ glycerol and stored at $-80^{\circ} \mathrm{C}$ for further study.

Conventional PCR assays. Pure cultures of each isolate were transferred to potato dextrose broth (Difco Laboratories, Detroit) and grown at 20 to $22^{\circ} \mathrm{C}$ for 5 to 7 days in an orbital shaker at 120 rpm (VWR International, Inc., West Chester, PA). Mycelia were harvested, lyophilized at $-80^{\circ} \mathrm{C}$ for $72 \mathrm{~h}$, and ground to fine powder using a high-speed mixer mill (Model MM301; Retsch Inc., Newtown, PA). Genomic DNA was extracted as described previously (6) and quantified using a TBS-380 minifluorometer (Turner Biosystems Inc., Sunnyvale, CA). To confirm the F. graminearum, $\mathrm{Fg} 16 \mathrm{NF} / \mathrm{R}$ primer pairs were used (28) to amplify purified genomic DNA of the 21 isolates of $F$. graminearum collected from potato, sugar beet, and wheat. In addition, genomic DNA extracted from pure cultures of three additional trichothecene-producing Fusarium spp. (F. culmorum, F. poae, and $F$. sporotrichoides), and three leaf spot pathogens of wheat (Pyrenophora tritici-repentis, Septoria tritici, and Stagonospora nodorum) were tested with the Tri5 primers (Table 2) as described previously (3). The primer pairs (Tri5-F/Tri5-R) for F. graminearum (3) were designed from sequences of Tri5-encoding trichodiene synthase gene $(7,8)$. PCR products were separated on $2 \%(\mathrm{wt} / \mathrm{vol})$ agarose (Amresco, Solon, $\mathrm{OH})$ gels and photographed with a Fluorochem 2200 Image System (Alpha Innotech Corp., San Leandro, CA).

Virulence assays. The 21 selected isolates of $F$. graminearum were evaluated for virulence on the susceptible wheat cv. Grandin in the greenhouse. The term "virulence" herein refers to ability of the isolate of $F$. graminearum to cause high or low disease severity on the susceptible wheat $\mathrm{cv}$. Grandin. Three seeds were sown in a six-inch pot filled with Sunshine Mix No. 1 (Fison Horticulture, Vancouver, BC, Canada). The fungal isolates were grown in the PDA medium and inoculum was prepared by washing the conidia from 7-day-old culture plates with sterile distilled water. The conidial concentration was adjusted to $4 \times 10^{4}$ conidia/ml using a hemacytometer. Nine wheat heads/isolate were inoculated with $20 \mathrm{ml}$ of inoculum of each isolate at anthesis $(\approx 6$ weeks after seeding). Wheat heads sprayed with sterile distilled water and two potato isolates of $F$. sambucinum were used as negative controls. Plants were incubated in a moist chamber for $48 \mathrm{~h}$ (with a mist of $15 \mathrm{~s}$ at 2 -min intervals) at $23^{\circ} \mathrm{C}$ and moved to greenhouse benches. Glumes and spikelets were evaluated for FHB severity 21 days after inoculation (DAI). FHB severity was estimated by counting infected spikelets in a head and expressed as percentages

TABLE 1. Isolate identity and different types of trichothecenes produced in the susceptible wheat cv. Grandin inoculated with Fusarium graminearum isolates collected from potato, sugar beet, and wheat

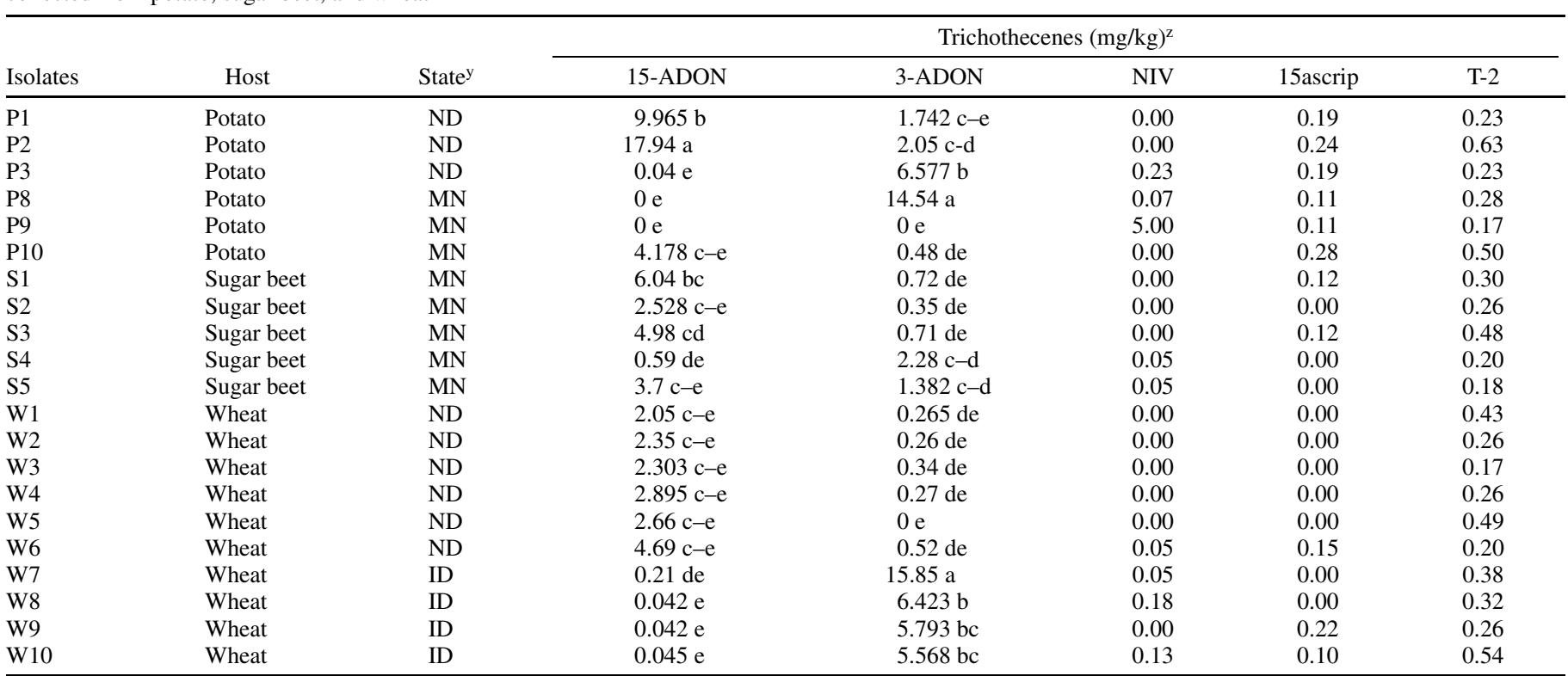

${ }^{\mathrm{y}} \mathrm{ID}=$ Idaho, $\mathrm{MN}=$ Minnesota, and ND = North Dakota.

${ }^{\mathrm{z}}$ Means with the same letter do not differ significantly $(P<0.01)$; 15- and 3-ADON $=15$ acetyldeoxynivalenol and 3acetyldeoxynivalenol, respectively; NIV $=$ nivalenol; 15 ascrip $=15$ acetylscripenol; and $\mathrm{T}-2=\mathrm{T}-2$ toxin .

TABLE 2. TaqMan primers and probe used in real-time polymerase chain reaction assays

\begin{tabular}{llcc}
\hline Primer $^{2}$ & \multicolumn{1}{c}{ Sequence $\left(5^{\prime}-3^{\prime}\right)$} & Annealing temperature $\left({ }^{\circ} \mathrm{C}\right)$ & Amplicon size $(\mathrm{bp})$ \\
\hline Tri5-F & TCTTAACACTAGCGTGCGCCTTCT & 60 & 193 \\
Tri5-R & CATGCCAACGATTGTTTGGAGGGA & 59.7 & 193 \\
Probe Tri5 & 5'FAM-AACAAGGCTGCCCACCACTTTGCTCAGCCT-TAMRA3' $^{\prime}$ & 68.3 & 193 \\
\hline
\end{tabular}

${ }^{\mathrm{z}}$ Primer orientation forward $(\mathrm{F})$ or reverse $(\mathrm{R})$. 
of total spikelets (38). The experiment was designed in a randomized complete block with three replicates. FHB severity values were calculated from nine inoculated wheat heads (three heads per replicate and a total of nine heads) per treatment and averaged to characterize each isolate. Two independent experiments were performed as biological replications, with each experiment including a virulence assay, a real-time PCR method, and mycotoxin production.

Real-time PCR assays. Wheat heads were detached from the plants after assessing FHB severity and stored at $-80^{\circ} \mathrm{C}$. Each sample was ground with liquid nitrogen using a mortar and pestle and DNA was extracted from $500 \mathrm{mg}$ of ground tissue. TaqMan probe was labeled at the $5^{\prime}$ end with the fluorescent reporter dye 6-carboxylfluoresceine (FAM) and at the $3^{\prime}$ end with $N, N, N^{\prime},-$ tetra-methyl-5-carboxyrhodamine (TAMRA). Both Tri5 primers and probe (Table 2) were synthesized by Operon Biotechnologies (Huntsville, AL).

Real-time PCR assays were performed in an iCycler (BioRad, Hercules, CA) in 96-well reaction plates and sealed with optical adhesive covers (BioRad). A series of real-time PCR assays was conducted at the beginning to determine the optimal primers and probe concentrations for $F$. graminearum. A standard curve was plotted from the five serial dilutions (ranging from $50 \mathrm{ng}$ to $5 \mathrm{pg}$ ) of purified genomic DNA of $F$. graminearum. To determine reproducibility of assays, independent experiments were performed with four purified genomic DNA concentrations $(50,5$, 0.5 , and $0.05 \mathrm{ng}$ ) of $F$. graminearum. To verify the effect of wheat DNA on FgDNA in real-time PCR assays, the first reaction mixture, with $50 \mathrm{ng}$ of FgDNA, and the second reaction mixture (1:1) with $50 \mathrm{ng}$ of wheat DNA and $50 \mathrm{ng}$ of FgDNA, were amplified with TaqMan probe and Tri5 primer sets. Each experiment was conducted in triplicate. DNA of the 21 isolates of $F$. graminearum extracted from the inoculated susceptible wheat cv. Grandin was quantified with the TaqMan probe and Tri5 primer sets. Genomic DNA isolated from pure cultures of the three trichothecene-producing Fusarium spp. (F. culmorum, F. poae, and $F$. sporotrichoides) were tested by a real-time PCR method. Genomic DNA of $F$. graminearum extracted from a pure culture and wheat DNA extracted from water-inoculated heads were used as positive and negative controls, respectively. Additional negative controls included sterile distilled water without the DNA template and $F$. sambucinum DNA extracted from the inoculated wheat heads. Each reaction $(25 \mu \mathrm{l})$ contained $2 \mu \mathrm{l}$ of DNA at $50 \mathrm{ng} / \mu \mathrm{l}$ extracted from the inoculated wheat heads, $12.5 \mu \mathrm{l}$ of iQ Supermix (BioRad) (100 mM KCl, $40 \mathrm{mM}$ Tris- $\mathrm{HCl}, \mathrm{pH} 8.4,1.6 \mathrm{mM}$ dNTPs, iTaq DNA polymerase at 50 units $/ \mathrm{ml}, 6 \mathrm{mM} \mathrm{MgCl}_{2}$, and stabilizers), $1.65 \mu \mathrm{l}$ of $750 \mathrm{nM}$ each reverse and forward primer, $1 \mu \mathrm{l}$ of $100 \mathrm{nM}$ TaqMan probe, and $6.2 \mu \mathrm{l}$ of sterile deionized water. The PCR cycling and temperatures were the same as described previously (3). Standard deviations were calculated for each treatment to monitor variations between technical replicates. Data were expressed as FgDNA content in picograms per $100 \mathrm{ng}$ of DNA extracted from inoculated wheat heads. PCR products were separated on a $2 \%$ (wt/vol) agarose gel in 0.5 Tris-borateEDTA (TBE, pH 8.0) buffer. Gels were stained with ethidium bromide $(10 \mathrm{mg} / \mathrm{ml})$ and photographed.

Mycotoxin analysis. Nine trichothecenes (Table 3) in the inoculated wheat heads were analyzed by gas chromatography (GC) and mass spectrometry (39). Quantitation limit and selected ion monitoring (SIM) mode were used for each mycotoxin analysis (Table 3 ).

Data analysis. Data from two biological replications were combined and averaged before statistical analyses. Mean comparison for FgDNA, FHB severity, and mycotoxin content in the inoculated wheat heads were analyzed using the SAS program (version 9.1, Statistical Analysis System; SAS Institute, Cary, NC). Linear correlation analysis of FgDNA versus FHB severity and mycotoxin production for each isolate was done (SAS Institute).

\section{RESULTS}

Identification of $\boldsymbol{F}$. graminearum. Morphological characteristics of the isolates collected from potato, sugar beet, and wheat were similar to $F$. graminearum. All isolates produced white fluffy mycelium, large distinct macroconidia, a carmine color underside on PDA plates, and perithecia on CLA.

Conventional PCR assays. The Fg16NF/R primer set amplified a 280-bp band only in the isolates of $F$. graminearum (Fig. 1A). Likewise, Tri5 primer pairs amplified a single band ( $\approx 193 \mathrm{bp})$ from all 21 isolates of $F$. graminearum and the three trichothecene-producing Fusarium spp. (Fig. 1B). No DNA was amplified from three leaf spot pathogens of wheat (Fig. 1B).

Virulence assays. The 21 isolates of $F$. graminearum induced typical FHB symptoms on the susceptible wheat cv. Grandin, whereas the 2 isolates $F$. sambucinum did not produce symptoms on wheat. Virulence differed significantly $(P \leq 0.05)$ among isolates. Two potato isolates (P2 and P3) collected from North Dakota were highly virulent, with FHB severity of 81 and $71 \%$, respectively (Fig. 2A). The sugar beet and wheat isolates were moderately to highly virulent and FHB severity ranged from 22 to 76\% (Fig. 2A and B).

Real-time PCR assays. There was no negative effect of wheat DNA on the amplification of FgDNA. TaqMan probe and Tri5 primer sets amplified a single band $(\approx 193 \mathrm{bp})$ from genomic DNA of three trichothecene-producing Fusarium spp. and DNA extracted from wheat heads inoculated with $F$. graminearum isolates (Fig. 1C). No DNA was amplified from water-inoculated wheat heads.

The coefficient of variation $(\mathrm{CV})$ of the cycle threshold $(\mathrm{Ct})$ values in the logarithm $(\log )$ linear phase of real-time PCR was $1.29,1.317,0.91$, and $0.89 \%$ at $50,5,0.5$, and $0.05 \mathrm{ng}$ per reaction, respectively. In addition, CV values for DNA template from the inoculated wheat heads with $F$. graminearum in two biological

TABLE 3. List of mycotoxins, methods, quantitation limits, and selected ion monitoring (SIM) mode used in trichothecene analyses of infected wheat inoculated with 21 Fusarium graminearum isolates collected from potato, sugar beet, and wheat

\begin{tabular}{|c|c|c|c|c|}
\hline \multirow[b]{2}{*}{ Toxin } & \multirow[b]{2}{*}{ Detection method ${ }^{\mathrm{z}}$} & \multirow[b]{2}{*}{ Quantitation limit (mg/kg) } & \multicolumn{2}{|c|}{ SIM mode (m/z value) } \\
\hline & & & Target ion & Reference ions (Q1, Q2) \\
\hline Deoxynivalenol (DON) & GC & 0.40 & 235.20 & $422.30,512.30$ \\
\hline 3Acetyldeoxynivlenol (3ADON) & $\mathrm{GC}$ & 0.08 & 377.10 & $163.10,467.20$ \\
\hline 15Acetyldeoxynivalenol (15ADON) & GC & 0.04 & 193.20 & $392.20,467.30$ \\
\hline Nivalenol (NIV) & GC & 0.08 & 289.20 & $379.20,482.30$ \\
\hline Diacetoxyscirpenol (DAS) & MS & 0.20 & 106.10 & $350.20,378.20$ \\
\hline 15Acetylscripenol (15ascrip) & MS & 0.08 & 159.10 & $285.20,408.30$ \\
\hline HT-2 toxin (HT-2) & MS & 0.10 & 347.20 & $466.30,245.20$ \\
\hline $\mathrm{T}-2$ toxin $(\mathrm{T}-2)$ & MS & 0.50 & 350.20 & $290.20,436.30$ \\
\hline Zearalenone & MS & 0.10 & 449.30 & $307.20,464.30$ \\
\hline
\end{tabular}

${ }^{\mathrm{z}}$ Detection method: $\mathrm{GC}=$ gas chromatography and $\mathrm{MS}=$ mass spectrometry. 
replications were low (between 2.36 and 2.49\%). The low CV values obtained from each independent real-time PCR assay revealed high reproducibility of the assay to quantify $F$. graminearum DNA in infected wheat. A standard curve showed a highly significant correlation between $\log _{10}$ of standard $F$. graminearum DNA quantities and their $\mathrm{Ct}$ values $(r=0.991, P<0.0001)$. Among the 21 isolates, the potato isolate $\mathrm{P} 3$ produced the highest FgDNA (914 pg) (Fig. 2A). FgDNA quantified in the sugar beet and the wheat isolates ranged from 136 to $510 \mathrm{pg}$ and 85 to 864 pg, respectively (Fig. 2A and B). Mean FgDNA ranged from 20 to $914 \mathrm{pg}$ per $100 \mathrm{ng}$ of DNA extracted from the inoculated wheat heads. The detection limit of our real-time PCR assay was 5 pg of $F$. graminearum DNA per assay.

Mycotoxin analysis. DON production varied significantly $(P<$ 0.01 ) among isolates (Fig. 2A and B). Two potato isolates (P2 and $\mathrm{P} 3$ ) produced higher DON than the sugar beet and wheat isolates (Fig. 2A and $\mathrm{B}$ ). The potato isolate $\mathrm{P} 2$ produced the highest 15 ADON $(18 \mathrm{mg} / \mathrm{kg})$, whereas the wheat isolate $\mathrm{W} 7$ produced the

A

12233455677899101112131415

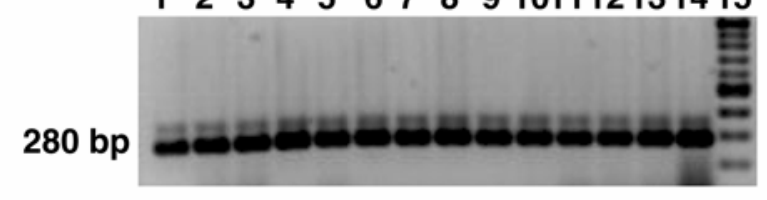

B

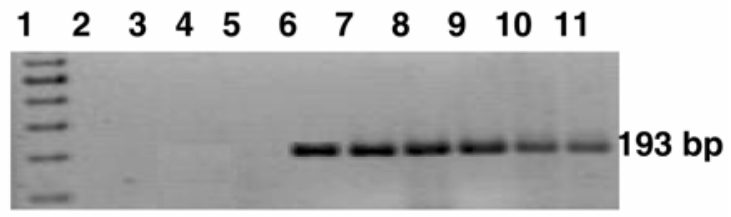

C

$\begin{array}{llllllllll}1 & 2 & 3 & 4 & 5 & 6 & 7 & 8 & 9 & 1011121314\end{array}$

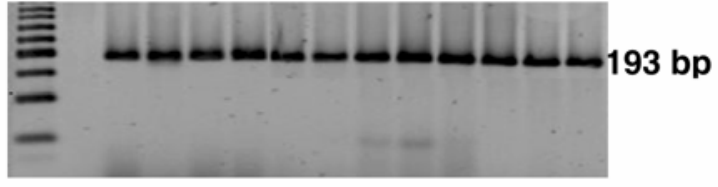

Fig. 1. Genomic DNA analyzed by conventional polymerase chain reaction (PCR) and real-time PCR method. A, Confirmation of representative isolates of Fusarium graminearum collected from potato, sugar beet, and wheat. Genomic DNA was isolated from pure cultures of $F$. graminearum amplified using $F$. graminearum-specific primer pairs $\mathrm{Fg} 16 \mathrm{NF} / \mathrm{R}$ by conventional PCR and separated on $2 \%(\mathrm{wt} / \mathrm{vol})$ agarose gel. PCR products were amplified with: lanes 1 to $5, F$. graminearum isolates collected from potato; lanes 6 to 10 , $F$. graminearum isolates collected from sugar beet; lanes 11 to $14, F$. graminearum isolates collected from wheat; lane 15, 100-bp ladder. B, Representative samples of conventional PCR products of $F$. graminearum and other trichothecene-producing Fusarium spp. amplified with primers Tri5 gene and separated on $2 \%(\mathrm{wt} / \mathrm{vol})$ agarose gel. Lane 1, 100-bp ladder; genomic DNA from lane 2, water-inoculated wheat head; lane 3, Pyrenophora tritici-repentis; lane 4, Stagonospora nodorum; lane 5, Septoria tritici; lanes 6 to 8 , $F$. graminearum recovered from potato, sugar beet, and wheat, respectively; lane $9, F$. sporotrichoides; lane $10, F$. culmorum; lane 11, F. poae. C, Representative samples of real-time PCR products of $F$. graminearum and other trichothecene-producing Fusarium spp. amplified with primers and probe specific to the Tri5 gene, and separated on $2 \%$ (wt/vol) agarose gel. Lane 1, 50-bp ladder; genomic DNA: from lane 2, water-inoculated wheat head; lane $3, F$. sporotrichoides; lane $4, F$. culmorum; lane $5, F$. poae; lanes 6 to 8 , $F$. graminearum collected from potato, sugar beet, and wheat, respectively; DNA of wheat head inoculated with $F$. graminearum isolates collected from lanes 9 and 10, potato; lanes 11 and 12, sugar beet; lanes 13 and 14, wheat. highest 3-ADON (16 mg/kg) (Table 1). Most sugar beet isolates produced $3-\mathrm{ADON}$ at $<1 \mathrm{mg} / \mathrm{kg}$, whereas these isolates formed relatively high $15-\mathrm{ADON}$. A negative correlation $(r=-0.34)$ was observed between 3-ADON and 15-ADON content in infected wheat heads (data not shown).

The potato isolate P9 produced the highest NIV $(5 \mathrm{mg} / \mathrm{kg})$ (Table 1). Both diacetoxyscirpenol and Ht-2 toxins were detected at $<0.1 \mathrm{mg} / \mathrm{kg}$ (data not shown). However, one wheat isolate, W6, formed $\mathrm{Ht}-2$ at $0.22 \mathrm{mg} / \mathrm{kg}$. All potato isolates produced 15Ascrip (ranging from 0.11 to $0.28 \mathrm{mg} / \mathrm{kg}$ ) (Table 1). In addition, 2 of the 5 sugar beet isolates and 3 of the 10 wheat isolates formed 15Ascrip. All isolates produced T-2 toxin at $<1 \mathrm{mg} / \mathrm{kg}$ (ranging from 0.17 to $0.63 \mathrm{mg} / \mathrm{kg}$ ). No zearalenone was detected from the inoculated wheat heads.

Relationships between FgDNA and FHB severity or mycotoxin production. Correlation analyses showed a significant

A

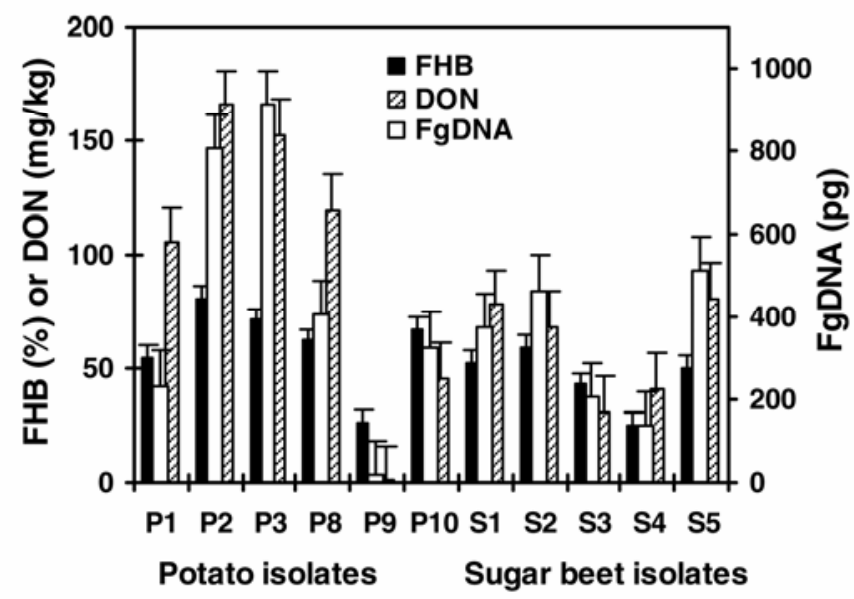

B

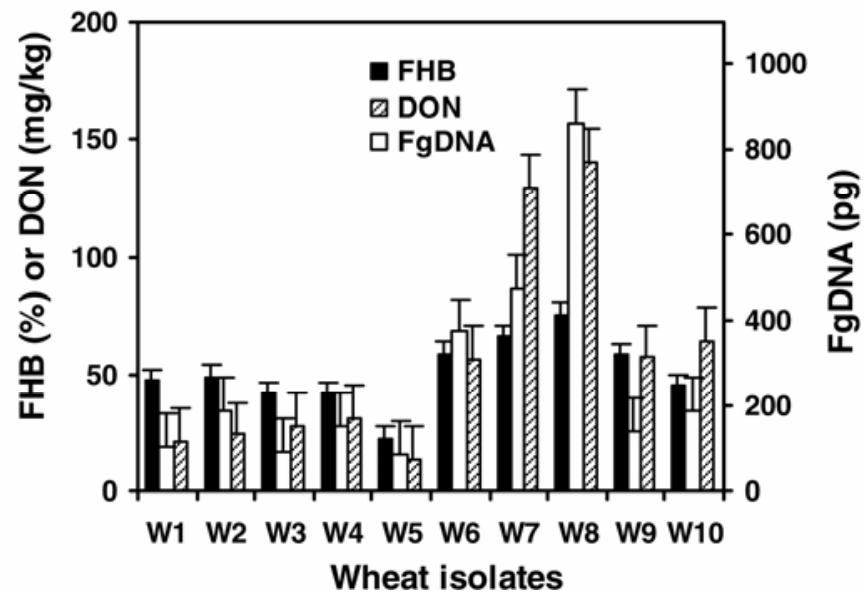

Fig. 2. Measurements of Fusarium graminearum DNA (FgDNA), Fusarium head blight (FHB) severity (\%), and deoxynivalenol (DON) content in the inoculated heads of the susceptible wheat cv. Grandin 21 days after inoculation. A, Wheat heads inoculated with six and five isolates of F. graminearum collected from potato and sugar beet, respectively. Potato isolates P1, P2, and P3 were collected from North Dakota and P8, P9, and P10 from Minnesota. Sugar beet isolates S1, S2, S3, S4, and S5 were collected from Minnesota. B, Wheat heads inoculated with 10 isolates of $F$. graminearum recovered from wheat: $\mathrm{W} 1, \mathrm{~W} 2, \mathrm{~W} 3, \mathrm{~W} 4, \mathrm{~W} 5$, and W6 were collected from North Dakota and W7, W8, W9, and W10 isolates were from Idaho. DNA concentration was picograms (pg) per 100 nanograms (ng) DNA was extracted from wheat heads inoculated with $F$. graminearum isolates. DON content was quantified in $\mathrm{mg} / \mathrm{kg}$ from the wheat heads inoculated with $F$. graminearum isolates. 
positive association $(r=0.819, P<0.001)$ between FgDNA and FHB severity (Fig. 3A) and between FHB severity and DON production $(r=0.817, P<0.001)$ (Fig. 3B). Also, a highly and significant positive correlation $(r=0.886, P<0.001)$ was found between FgDNA and DON content (Fig. 3C).

\section{DISCUSSION}

The combination of cultural, morphological, and molecular techniques used in this study allowed us to detect and identify isolates of $F$. graminearum collected from potato, sugar beet, and wheat. Each isolate produced white fluffy mycelium and distinct macroconidia on PDA and CLA (26). All isolates produced perithecia and yielded a 280-bp PCR product with the Fg16NF/R primers specific to $F$. graminearum (28). This study demonstrated that the $F$. graminearum isolates collected from potato and sugar beet induced typical FHB symptoms in the susceptible wheat cultivar and are capable of producing a wide range of trichothecenes. The real-time PCR method was sensitive and reproducible to quantify $F$. graminearum DNA from the infected wheat heads. Sensitivity of the real-time PCR assay was similar to that achieved in previous works $(35,37)$.

Significant variation among isolates in relation to virulence, FgDNA, and mycotoxin production was observed. Most of the potato and the sugar beet isolates produced equal or even higher FHB severity, FgDNA, and mycotoxin production compared with the wheat isolates. Isolates with higher virulence also produced higher FgDNA content and more mycotoxin accumulation than less virulent isolates, suggesting that the differences in virulence among isolates of $F$. graminearum could be attributed to differences in the ability of pathogen to infect wheat tissues and accumulation of mycotoxins in wheat grains. Both DON and other trichothecenes produced have been shown to contribute virulence or aggressiveness of $F$. graminearum $(10,14,16,23)$. Correlation analyses showed strong associations among FgDNA, FHB severity, and DON content. These results corroborate previous studies where highly significant correlations were reported between FgDNA and FHB severity (42), between FgDNA and DON content $(11,36)$, and between FHB and trichothecenes content $(19,23)$. Similarly, highly positive correlations were observed among FHB severity, FgDNA, and DON concentration in wheat and other cereals infected by $F$. graminearum $(13,18,24,25)$.

Potato isolates showed greater variability in producing different mycotoxins than sugar beet and wheat isolates. Most potato isolates produced high levels of DON. One isolate, P9, which produced the highest NIV leveks, did not produce any other trichothecenes except DON $(0.95 \mathrm{mg} / \mathrm{kg})$. Likewise, this potato isolate with low FHB severity did not yield high FgDNA content. This suggested that the NIV producer formed low levels of DON and other trichothecenes. Desjardins et al. (9) reported that NIV producers occasionally formed low DON in infected grains. Three potato isolates produced relatively higher $15-\mathrm{ADON}$, whereas two potato isolates formed higher 3-ADON. Most of the sugar beet isolates produced 15-ADON. The wheat isolates collected from North Dakota produced 15-ADON, whereas isolates collected from Idaho produced 3-ADON. The reasons for those differences are unknown. Analysis of the differences in DNA fingerprints separated the North American populations of $F$. graminearum into lineage $7(30,43)$. However, our current data may not be sufficient to evaluate hypotheses concerning the picture of pathogen evolution in $F$. graminearum. Comparison of the sequences between potato and sugar beet isolates with wheat isolates may provide additional insertions or deletions that occurred in some repeats of $F$. graminearum (40).

Among the most agriculturally important Fusarium spp., F. graminearum is the principal cause of FHB in North America (22), whereas F. culmorum is prevalent in northwest Europe (27). We used a real-time PCR method based on the sequences of the
Tri5 gene to successfully detect and quantify DNA of each isolate of $F$. graminearum from artificially inoculated wheat heads in controlled environments. Although the susceptible wheat cv. Grandin was not inoculated with the three members of trichothecene-producing Fusarium spp. (F. culorum, F. poae, and F. sporotrichoides), genomic DNA extracted from pure cultures of these

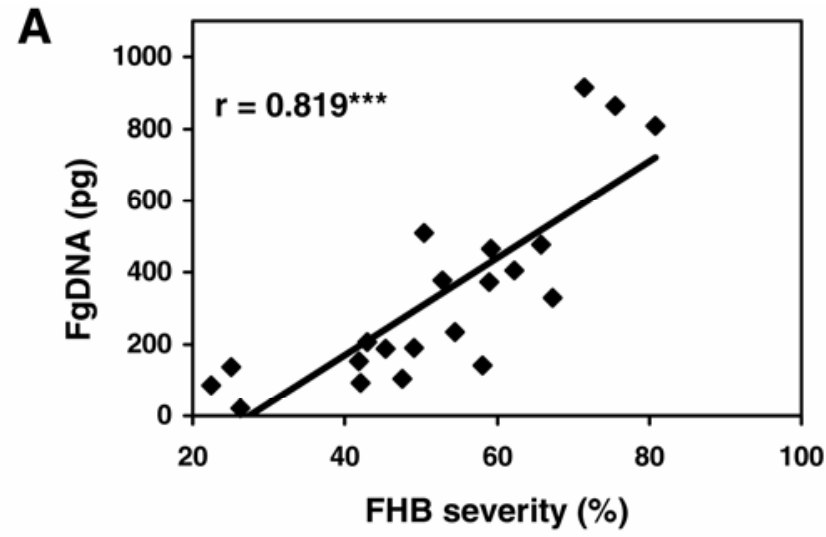

B
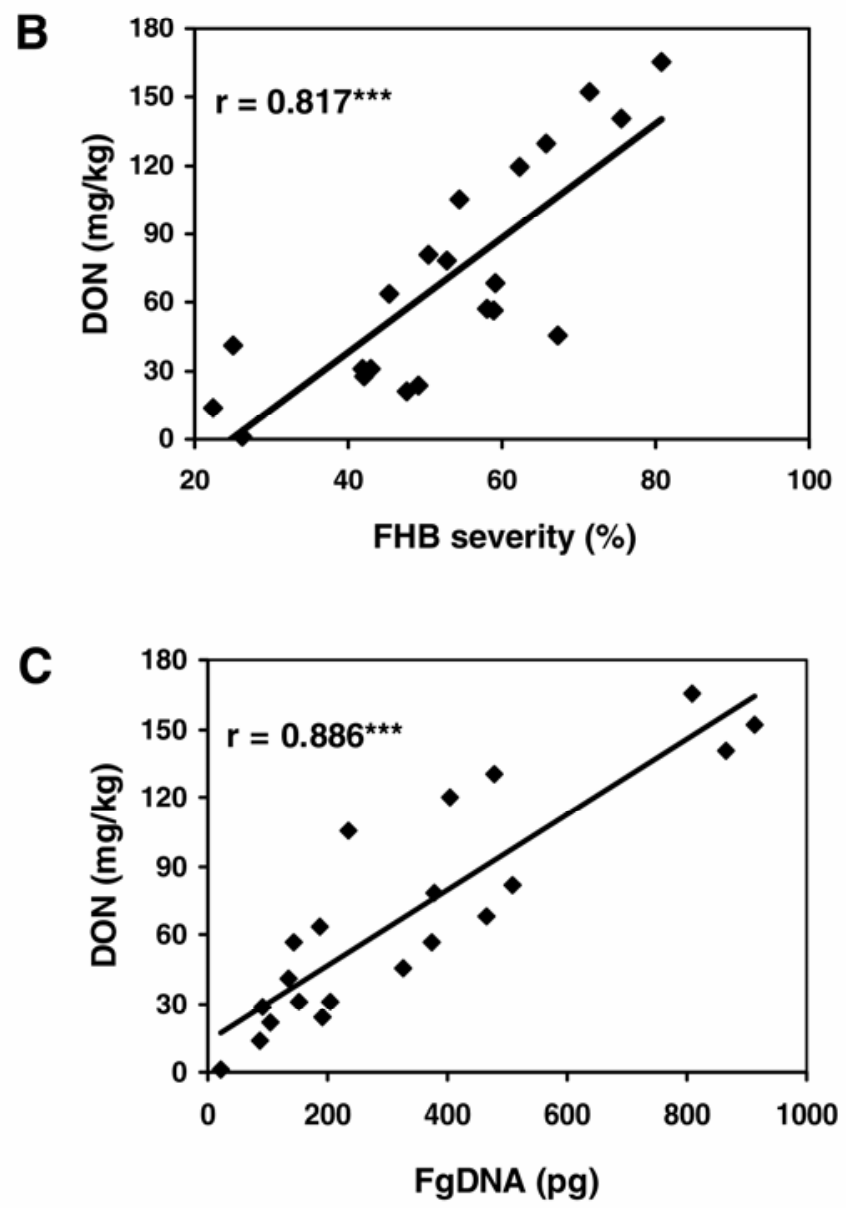

Fig. 3. Relationships between Fusarium graminearum DNA content, Fusarium head blight (FHB) severity, and deoxynivalenol (DON) content in the wheat heads inoculated with the 21 isolates of $F$. graminearum collected from potato, sugar beet, and wheat. A, Correlation analysis of FHB severity was estimated visually and $F$. graminearum DNA content was quantified by realtime polymerase chain reaction (PCR). B, Correlation analysis of FHB severity was estimated visually and DON content was determined by gas chromatography (GC). C, Correlation analysis of $F$. graminearum DNA content was quantified by real-time PCR and DON content was analyzed with GC. DNA concentration was picograms (pg) per 100 nanograms (ng) of DNA extracted from the wheat heads inoculated with $F$. graminearum isolates. DON content was quantified in $\mathrm{mg} / \mathrm{kg}$ from the wheat heads inoculated with $F$. graminearum isolates; $* * *$ indicates significant at $P<0.001$. 
species showed positive reaction for the Tri5 gene, indicating that these species contain homologs of the FgTri5 cluster (7). For field studies where these three trichothecene-producing Fusarium spp. are prevalent, the results of this study imply a need to carefully select additional primers specific to $F$. graminearum. In such cases, combining a real-time PCR method with conventional PCR could increase specificity of the assay.

In conclusion, the potato and sugar beet isolates could be a potential threat in wheat and other small grains because the isolates tested here induced typical FHB symptoms on wheat and formed significant amount of mycotoxins that are hazardous to both human and animal health. The real-time PCR method used here, together with virulence tests and chemotype groups, will be useful in resistant breeding programs. Further ecological and epidemiological studies are necessary to understand the effects of crop residues, inoculum potential, and crop rotation on the FHB management in small grains.

\section{ACKNOWLEDGMENTS}

This was a cooperative project with the United States Wheat and Barley Scab Initiative, and part of this work was supported by the United States Department of Agriculture under Agreement No. 59-0790-5-076. We thank M. Bonman, N. C. Gudmestad, S. Gyawali, and J. Rasmussen for reviewing the manuscript; J. Windes and J. Miller for providing isolates of F. graminearum from Idaho; and S. Ali, P. Burlakoti, and M. Fakhr for their technical assistance.

\section{LITERATURE CITED}

1. Ali, S., Rivera, V. V., and Secor, G. A. 2005. First report of Fusarium graminearum causing dry rot of potato in North Dakota. Plant Dis. $89: 105$.

2. Bai, G. H., and Shaner, G. 2004. Management of wheat and barley to Fusarium head blight. Annu. Rev. Phytopathol. 42:135-161.

3. Boddeda, A. 2006. Development and application of multiple polymerase chain reaction assays to detect ochratoxin producing Aspergillus and Penicillium, and trichothecene producing Fusarium in stored and processed grain. Ph. D. thesis, North Dakota State University, Fargo.

4. Broders, K. D., Lipps, P. E., and Dorrance, A. E. 2007. Evaluation of F. graminearum as a seed and seedling pathogen of corn and soybean in Ohio. (Abstr.) Phytopathology 97(suppl.):S159.

5. Chongo, G., Gossen, B. D., Kutcher, H. R., Gilbert, J., Turkington, T. K., Fernandez, M. R., and McLaren, D. 2001. Reaction of seedling roots of 14 crop species to Fusarium graminearum from wheat heads. Can. J. Plant Pathol. 23:132-137.

6. Demeke, T., Clear, R. M., Patrick, S. K., and Gaba, D. 2005. Species-specific PCR-based assays for the detection of Fusarium species and a comparison with the whole seed agar plate method and trichothecene analysis. Int. J. Food Microbiol. 103:271-284.

7. Desjardins, A. E. 2006. Fusarium Mycotoxins Chemistry, Genetics and Biology. The American Phytopathological Society Press, St. Paul, MN.

8. Desjardins, A. E., Hohn, T. M., and McCormick, S. 1992. Effect of gene disruption of trichodiene synthase on the virulence of Gibberella pulicaris. Mol. Plant-Microbe Interact. 5:214-222.

9. Desjardins, A. E., Jarosz, A. M., Plattner, R. D., Alexander, N. J., Brown, D. W., and Jurgenson, J. E. 2004. Patterns of trichothecene production, genetic variability, and virulence to wheat of Fusarium graminearum from smallholder farms in Nepal. J. Agric. Food Chem. 52:6341-6346.

10. Desjardins, A., Proctor, R. H., Bai, G. H., McCormick, S. P., Shaner, G., Buechley G., and Hohn, T. M. 1996. Reduced virulence of trichothecenedeficient mutants of Gibberella zeae in wheat field tests. Mol. Plant-Microbe Interact. 9:775-781.

11. Edwards, S. G., Pirgozliev, S. R., Hare, M. C., and Jenkinson, P. 2001. Quantification of trichothecene-producing Fusarium species in harvested grain by competitive PCR to determine efficacies of fungicides against Fusarium head blight of winter wheat. Appl. Environ. Microbiol. 67:1575-1580.

12. Estrada Jr., R., Rivera, V. V., and Secor, G. A. 2007. Pathogenicity of Fusarium graminearum to potato, sugar beet, and wheat. (Abstr.) Phytopathology 97(suppl.):S160.

13. Gang, G., Miedaner, T., Schuhmacher, U., Schollenberger, M., and Geiger, H. H. 1998. Deoxynivalenol and nivalenol production by Fusarium culmorum isolates differing in aggressiveness toward winter rye. Phytopathology 88:879-884
14. Goswami, R. S., and Kistler, H. C. 2005. Pathogenicity and in planta mycotoxin accumulation among members of Fusarium graminearum species complex on wheat and rice. Phytopathology 95:1397-1404.

15. Hanson, L. E. 2006. Fusarium yellowing of sugar beet caused by Fusarium graminearum from Minnesota and Wyoming. Plant Dis. 90:686.

16. Harris, L. J., Desjardins, A. E., Plattner, R. D., Nicholson, P., Butler, G., Young, J. C., Weston, G., Proctor, R. H., and Hohn, T. M. 1999. Possible role of trichothecene mycotoxins in virulence of Fusarium graminearum on maize. Plant Dis. 83:954-960.

17. Komada, H. 1975. Development of a selective medium for quantitative isolation of Fusarium oxysporum from natural soils. Rev. Plant Prot. Res. 8:114-125.

18. Lamper, C. S., Teren, J., Bartok, T., Komoroczy, R., Mesterhazy, A., and Sagi, F. 2000. Predicting DON contamination in Fusarium infected wheat grains via determination of the ergosterol content. Cereal Res. Commun. 28:337-344.

19. Liu, W., Langseth, W., Skinnes, H., Elen, O. N., and Sundheim, L. 1997. Comparison of visual head blight ratings, seed infection levels, and deoxynivalenol production for assessment of resistance in cereals inoculated with Fusarium culmorum. Eur. J. Plant Pathol. 103:589-595.

20. Marasas, W. F. O., Nelson, P. E., and Toussoun, T. A., 1984. Toxigenic Fusarium Species: Identity and Mycotoxicology. The Pennsylvania State University Press, University Park.

21. Martinelli, J. A., Bocchese, C. A. C., Xie, W., O’Donnell, K., and Kistler, H. C. 2004. Soybean pod blight and root rot caused by lineages of the Fusarium graminearum and the production of mycotoxins. Fitopatol. Bras. 29:492-497.

22. McMullen, M., Jones, R., and Gallenberg, D. 1997. Scab of wheat and barley: A re-emerging disease of devastating impact. Plant Dis. 81:13401348 .

23. Mesterhazy, A. 2002. Role of deoxynivalenol in aggressiveness of Fusarium graminearum and $F$. culmorum and in resistance to Fusarium head blight. Eur. J. Plant Pathol. 108:675-684.

24. Miedaner, T., and Perkoski, J. 1996. Correlations among Fusarium culmorum head blight resistance, fungal colonization and mycotoxin contents in winter rye. Plant Breed. 115:347-351.

25. Miedaner, T., Reinbrecht, C, and Schilling, A. G. 2000. Association among aggressiveness, fungal colonization and mycotoxin production of 26 isolates of Fusarium graminearum in winter rye head blight. J. Plant Dis. Prot. 107:124-134.

26. Nelson, P. E., Toussoun, T. A., and Marasas, W. F. O. 1983. Fusarium Species: An Illustrated Manual for Identification. Pennsylvania State University Press, University Park.

27. Nicholson, P., Chandler, E., Draeger, R. C., Gosman, N. E., Simpson, D. R., Thomsett, M., and Wilson, A. H. 2003. Molecular tools to study epidemiology and toxicology of Fusarium head blight cereals. Eur. J. Plant Pathol. 109:691-703.

28. Nicholson, P., Simpson, D. R., Weston, G., Rezanoor, H. N., Lees. K., Parry, D. W., and Joyce, D. 1998. Detection and quantification of Fusarium culmorum and Fusarium graminearum in cereals using PCR assays. Physiol. Mol. Plant Pathol. 53:17-37.

29. Niessen, L., Klusmann, J., and Vogel, R. F. 1998. Quantitative estimation of Fusarium graminearum DNA using a solid phase PCR assay (DIAPOPS). J. Food Mycol. 1:73-84.

30. O’Donnell, K., Kistler, H. C., Tacke, B. K., and Casper, H. H. 2000. Gene genealogies reveal global phylogeographic structure and reproductive isolation among lineages of Fusarium graminearum, the fungus causing wheat scab. Proc. Natl. Acad. Sci. USA 97:7905-7910.

31. Parry, D. W., Jenkinson, P., and McLeod, L. 1995. Fusarium ear blight (scab) in small grain cereals-a review. Plant Pathol. 44:207-238.

32. Placinta, C. M., D’Mello, J. P. F., and McDonald, A. M. C. 1999. A review of worldwide contamination of cereal grains and animal feed with Fusarium mycotoxins. Anim. Feed Sci. Technol. 78:21-37.

33. Reischer, G. H., Lemmens, M., Farnleitner, A., Adler, A., and Mach, R. L. 2004. Quantification of Fusarium graminearum in infected wheat by species specific real-time PCR applying a TaqMan probe. J. Microbiol. Methods 59:141-146.

34. Schena, L., Franco, N., Ippolito, A., and Gallitelli, D. 2004. Real-time quantitative PCR: a new technology to detect and study phytopathogenic and antagonistic fungi. Eur. J. Plant Pathol. 110:893-908.

35. Schnerr, H., Niessen, L., and Vogel, R. F. 2001. Real time detection of the Tri5 gene in Fusarium species by lightcycler-PCR using SYBR green I for continuous fluorescence monitoring. Int. J. Food Microbiol. 71:53-61.

36. Schnerr, H., Vogel, R. F., and Niessen, L. 2002. Correlation between DNA of trichothecene-producing Fusarium species and deoxynivalenol concentrations in wheat samples. Lett. Appl. Microbiol. 35:121-125.

37. Silvar, C., Diaz, J., and Merino, F. 2005. Real-time polymerase chain reaction quantification of Phytophthora capsici in different pepper genotypes. Phytopathology 95:1423-1429.

38. Stack, R. W., and McMullen, M. P. 1998. A visual scale to estimate 
Fusarium head blight in wheat. N.D. State Univ. Ext. Serv., Fargo PP1095.

39. Tacke, B. H., and Casper, H. H. 1996. Determination of deoxynivalenol in wheat, barley and malt by column cleanup and gas chromatography with electron capture detection. J. AOAC Int. 79:472-475.

40. Waalwijk, C, Kastelein, P., de Vries, I., Kerenyi, Z., van der Lee, T., Hesselink, T., Kohl, J., and Kema, G. H. J. 2003. Major changes in Fusarium spp. in wheat in the Netherlands. Eur. J. Plant Pathol.109:743754.

41. Waalwijk, C., van der Heide, R., de Vries, I., van der Lee, T., Schoen, C., Costrel-de Corainville, G., Hauser-Hahn, I., Kastelein, P., Kohl, J.,
Lonnet, P., Demarquet, T., and Kema, G. H. J. 2004. Quantitative detection of Fusarium species in wheat using TaqMan. Eur. J. Plant Pathol. 110:481-494.

42. Wang, Y. Z., and Miller, J. D. 1988. Screening techniques and sources of resistance to Fusarium head blight. Pages 239-250 in: Wheat Production Constraints in Tropical Environments. A. R. Klatt, ed. CIMMYT, Mexico, D.F.

43. Ward, T. J., Bielawski, J. P., Kistler, H. C., Sullivan, E., and O’Donnell, K. 2002. Ancestral polymorphism and adaptive evolution in the trichothecene mycotoxin gene cluster of phytopathogenic Fusarium. Proc. Natl. Acad. Sci. USA 99:9278-9283. 